\title{
Changes in Nicotinic Neurotransmission during Enteric Nervous System Development
}

\author{
Jaime Pei Pei Foong, ${ }^{1}$ Caroline S. Hirst, ${ }^{2}$ Marlene M. Hao, ${ }^{3}$ Sonja J. McKeown, ${ }^{2}$ Werend Boesmans, ${ }^{3}$ \\ ${ }^{-}$Heather M. Young, ${ }^{2 *}{ }^{-}$Joel C. Bornstein, ${ }^{1 *}$ and Pieter Vanden Berghe ${ }^{3 *}$ \\ ${ }^{1}$ Departments of Physiology and ${ }^{2}$ Anatomy and Neuroscience, University of Melbourne, Victoria 3010, Australia and ${ }^{3}$ Laboratory for Enteric NeuroScience \\ (LENS), Translational Research Center for Gastrointestinal Disorders (TARGID), University of Leuven, 3000 Leuven, Belgium
}

Acetylcholine-activating pentameric nicotinic receptors (nAChRs) are an essential mode of neurotransmission in the enteric nervous system (ENS). In this study, we examined the functional development of specific nAChR subtypes in myenteric neurons using Wnt1-Cre; R26R-GCaMP3 mice, where all enteric neurons and glia express the genetically encoded calcium indicator, GCaMP3. Transcripts encoding $\alpha 3, \alpha 4, \alpha 7, \beta 2$, and $\beta 4 \mathrm{nAChR}$ subunits were already expressed at low levels in the E11.5 gut and by E14.5 and, thereafter, $\alpha 3$ and $\beta 4$ transcripts were the most abundant. The effect of specific nAChR subtype antagonists on evoked calcium activity in enteric neurons was investigated at different ages. Blockade of the $\alpha 3 \beta 4$ receptors reduced electrically and chemically evoked calcium responses at E12.5, $\mathrm{E} 14.5$, and $\mathrm{P} 0$. In addition to the $\alpha 3 \beta 4$ antagonist, antagonists to $\alpha 3 \beta 2$ and $\alpha 4 \beta 2$ also significantly reduced responses by P10 - 11 and in adult preparations. Therefore, there is an increase in the diversity of functional nAChRs during postnatal development. However, an $\alpha 7$ nAChR antagonist had no effect at any age. Furthermore, at E12.5 we found evidence for unconventional receptors that were responsive to the nAChR agonists 1-dimethyl-4-phenylpiperazinium and nicotine, but were insensitive to the general nicotinic blocker, hexamethonium. Migration, differentiation, and neuritogenesis assays did not reveal a role for nAChRs in these processes during embryonic development. In conclusion, there are significant changes in the contribution of different nAChR subunits to synaptic transmission during ENS development, even after birth. This is the first study to investigate the development of cholinergic transmission in the ENS.

Key words: development; enteric nervous system; neurotransmission; nicotinic receptor

\section{Introduction}

The enteric nervous system (ENS) is a complex network of neurons and glia within the gastrointestinal tract. Communication between enteric neurons is vital for regulating several gut functions including motility (Furness, 2012). Although there are many forms of synaptic transmission in the mature ENS, fast excitatory transmission mediated by acetylcholine activating nicotinic receptors (nAChRs) is an essential mode of communication between most enteric neurons (Galligan and North, 2004; Gwynne and Bornstein, 2007). Neuronal nAChRs are fast ionotropic cationic channels. To date, eight $\alpha$-subunits and three $\beta$-subunits that contribute to the homopentameric or heteropen-

\footnotetext{
Received Oct. 9, 2014; revised Feb. 10, 2015; accepted March 27, 2015.

Author contributions: J.P.P.F., H.M.Y., J.C.B., and P.V.B. designed research; J.P.P.F., C.S.H., M.M.H., S.J.M., and W.B. performed research; J.P.P.F., C.S.H., M.M.H., S.J.M., W.B., H.M.Y., J.C.B., and P.V.B. analyzed data; J.P.P.F., C.S.H., M.M.H., S.J.M., W.B., H.M.Y., J.C.B., and P.V.B. wrote the paper.

This work was supported by an Australian Research Council Discovery Grant DP130101596 (to J.C.B., H.M.Y., and P.V.B.) and FWO (G.501.10) and KU Leuven 1/10/046 (to P.V.B.). M.H.H. and W.B. are postdoctoral fellows of the FWO. We thank Hideki Enomoto for the Ednrb ${ }^{\text {KikGR }}$ mice; Vassilis Pachnis for the Wnt1-Cre mice; Vanda Lennon and Piers Emson for antisera; and Annette Bergner, Franca Casagranda, and the members of LENS for their technical assistance and helpful advice.

${ }^{*}$ H.M.Y., J.C.B., and P.V.B. contributed equally to this work.

The authors declare no competing financial interests.

Correspondence should be addressed to Pieter Vanden Berghe, Laboratory for Enteric NeuroScience (LENS), Translational Research Center for Gastrointestinal Disorders (TARGID), University of Leuven, Herestraat 49, 3000 Leuven, Belgium. E-mail: Pieter.VandenBerghe@med.kuleuven.be.

DOI:10.1523/JNEUROSCI.4175-14.2015

Copyright $\odot 2015$ the authors $\quad 0270-6474 / 15 / 357106-10 \$ 15.00 / 0$
}

tameric structure of these channels have been cloned from mammals (Papke, 2014). The diverse composition of nAChR subunits affects receptor affinity to nicotine, ion permeability, desensitization, and thus function (Albuquerque et al., 2009). In the guinea pig myenteric plexus $\alpha 3 \beta 2, \alpha 3 \beta 4$, and/or $\alpha 7$ nAChRs mediate excitatory (particularly fEPSPs) and inhibitory pathways (Obaid et al., 2005).

The ENS derives from the vagal, sacral, and rostral truncal neural crest (Gershon, 1998). Enteric neural crest cells (ENCCs) must also differentiate into neurons and glia and then form appropriate synapses. While the genes and molecules involved in ENS development have been extensively studied, the physiological development of the ENS remains poorly understood (Sasselli et al., 2012; Lake and Heuckeroth, 2013). Some ENCCs from short-term, cultured E11.5 mouse gut exhibit spontaneous intracellular calcium concentration fluctuations and fire action potentials (Hao et al., 2011, 2012). Although enteric synapses appear ultrastructurally mature by E16.5 (Vannucchi and FaussonePellegrini, 2000), it is unknown whether they are functional. Neurally mediated gut motility only commences at E18.5 (Roberts et al., 2010). Moreover, significant physiological maturation occurs during the first 10 postnatal days and extends well into postnatal stages (for review, see Hao et al., 2013b).

There is evidence suggesting that nicotinic fast excitatory neurotransmission is one of the first forms of neuronal communication in the murine ENS. The acetylcholine synthetic enzyme, 
Table 1. nAChR subtype specific TaqMan Gene Expression Assays (Life Technologies) used for Droplet Digital PCR

\begin{tabular}{llc}
\hline Assay ID & nAChR subunit & Entrez gene ID \\
\hline Mm00520145_m1 & $\alpha 3$ & 110834 \\
Mm00516561_m1 & $\alpha 4$ & 11438 \\
Mm01312230_m1 & $\alpha 7$ & 11441 \\
Mm00515323_m1 & $\beta 2$ & 11444 \\
Mm00804952_m1 & $\beta 4$ & 108015 \\
\hline
\end{tabular}

ChAT, is one of the earliest neurochemical markers expressed in the developing ENS (by E10.5), and adult proportions of ChAT neurons are achieved in the small intestine and colon by E13.5 and P0, respectively (Rothman and Gershon, 1982; Erickson et al., 2014). Cultured neurons from dissociated E11.5 and E12.5 gut exhibit calcium transients evoked by nAChR activation and fEPSP-like events (Hao et al., 2011, 2012). Additionally, P0 and P10 myenteric neurons and neurons generated from enteric neural crest-derived ENS progenitors transplanted into the colon of postnatal recipient mice display nAChR-mediated fEPSPs (Foong et al., 2012; Hotta et al., 2013).

In this study, we used mice in which all neural crest-derived cells express the genetically encoded calcium indicator, GCaMP3 (Boesmans et al., 2013), to study the role of specific nAChR subtype blockers on the activity of myenteric neurons at different ages. We show that some $\mathrm{nAChR}$ subtypes are already present by E11.5, but that the diversity of functional subtypes increases during development. Furthermore, unconventional hexamethonium-insensitive nicotinic receptors are present early in ENS development.

\section{Materials and Methods}

Animals

The following mice of either sex were used: C57BL/6 mice, $E d n r b^{K i k G R}$ mice in which all enteric neural crest-derived cells express the fluorescent protein, KikGR, under the control of an enteric-specific region of the Ednrb promoter (Nishiyama et al., 2012); Wnt1-Cre;R26R-GCaMP3 mice, where all neural crest-derived cells express the genetically encoded calcium indicator, GCaMP3 (Zariwala et al., 2012; Boesmans et al., 2013); and ChAT-Cre;R26R-YFP mice (Hao et al., 2013a). Wnt1-Cre; R26R-GCaMP3 mice were bred by mating Wnt1-Cre mice (Danielian et al., 1998) with R26R-GCaMP3 mice (The Jackson Laboratory). ChATCre;R26R-YFP mice were bred by mating ChAT-Cre mice with R26R-YFP reporter mice (both from The Jackson Laboratory). The morning a copulatory plug was found was designated E0.5. P10 and older mice were killed by cervical dislocation while $\mathrm{P} 0$ and embryonic mice were killed by decapitation. All procedures are approved by the Animal Ethics Committees of the University of Leuven (KU Leuven) and the University of Melbourne.

\section{Quantitative expression of $n A C h R$ subtypes using Droplet} Digital PCR

Total RNA was extracted from E11.5 and E14.5 whole intestines (entire intestine caudal to the stomach) and P0, P10, and adult duodenum (myenteric plexus with attached smooth muscle layers) from C57BL/6 mice. This was done using QIAshredder and RNeasy Mini Kit (Qiagen), including the on-column DNase treatment, according to manufacturer's instructions. RNA concentration and integrity were measured using a 2200 TapeStation Instrument (Agilent). cDNA was synthesized using the iScript Advanced cDNA Synthesis Kit for RT-qPCR (Bio-Rad); $500 \mathrm{ng}$ of total RNA in a final reaction volume of $20 \mu \mathrm{l}$ reaction was converted to cDNA for each age.

Absolute quantification of target transcripts was determined by Droplet Digital PCR, using TaqMan Gene Expression Assays (Life Technologies; Table 1) and the QX100 Droplet Digital PCR system (Bio-Rad) according to manufacturer's instructions. Briefly, for each assay a $25 \mu \mathrm{l}$ final volume PCR mix was prepared containing $1 \mu \mathrm{l}$ of cDNA (diluted 1:10), $12.5 \mu \mathrm{l} 2 \times$ ddPCR Supermix for probes (Bio-Rad), and $1.25 \mu \mathrm{l}$
20× TaqMan Gene Expression Assays (Life Technologies). Subsequent droplet generation and PCR amplification were performed using $20 \mu \mathrm{l}$ of PCR mix. PCR amplification was performed on a C1000 Touch Thermal Cycler (Bio-Rad) using the following conditions: 1 cycle at $95^{\circ} \mathrm{C}$ for 10 min, 40 cycles at $94^{\circ} \mathrm{C}$ for $30 \mathrm{~s}$ and $60^{\circ} \mathrm{C}$ for $1 \mathrm{~min}$, and 1 cycle at $98^{\circ} \mathrm{C}$ for $10 \mathrm{~min}$, all at a ramp rate of $2.5^{\circ} \mathrm{C} / \mathrm{s}$. Absolute quantification of each transcript was calculated using the Quantasoft v1.7.4 (Bio-Rad) and represented as copies of transcript per microliter of amplified PCR mixture. Droplet Digital PCR does not require calibration curves or endogenous controls. Standard reagents and consumables supplied by Bio-Rad were used including cartridges and gaskets, droplet generation oil, and droplet reader oil. A VIAFLO 125 electronic pipette (Integra) was used to achieve high-precision pipetting. A no template control and a negative control for each reverse transcription reaction were included in every assay.

Statistical comparisons of transcript concentration were performed using $2 \times 2 \chi^{2}$ tests to compare the proportion of positive droplets between E11.5 versus E14.5 and one-way ANOVAs to compare mean transcript concentration between $\mathrm{P} 0, \mathrm{P} 10$, and adult.

\section{Calcium imaging}

Tissue preparation. Specific intestinal regions were removed from Wnt1Cre; R26R-GCaMP3 mice and immediately placed in physiological saline containing the following (in $\mathrm{mM}$ ): $120.9 \mathrm{NaCl}, 5.9 \mathrm{KCl}, 1.2 \mathrm{MgCl}_{2}, 2.5$ $\mathrm{CaCl}_{2}, 1.2 \mathrm{NaH}_{2} \mathrm{PO}_{4}, 14.4 \mathrm{NaHCO}_{3}$, and 11.5 glucose (containing $1 \mu \mathrm{M}$ nifedipine), bubbled with $95 \% \mathrm{O}_{2}-5 \% \mathrm{CO}_{2}$. For postnatal tissues, the duodenal segments (just below the stomach) were cut along the mesenteric border and pinned flat, mucosa side up, in a dish lined with silicone elastomer (Sylgard 184; Dow Corning). The mucosa and submucous plexus were removed from the underlying smooth muscle and myenteric plexus layers. Strips of circular muscle were carefully peeled off (for P10-P11 and adult preparations) and the resultant longitudinal musclemyenteric plexus (LMMP) preparations were stretched over a small inox ring and immobilized by a matched rubber $\mathrm{O}$-ring and placed in an organ bath (Roosen et al., 2012). A maximum of five LMMP preparations were obtained from each adult duodenum, while two preparations were obtained from each $\mathrm{P} 0$ and $\mathrm{P} 10-\mathrm{P} 11$ mouse. E14.5 proximal small intestine was cut along the mesenteric border and pinned flat, serosal side up, in the organ bath. E12.5 proximal small intestine and colon were mounted as intact tubes across a slit cut in filter paper supports (Hearn et al., 1999).

Imaging. The tissue was constantly superfused with physiological saline at room temperature via a gravity-fed electronic valve system that allowed switching (in $<1 \mathrm{~s}$ ) between saline and drug-containing saline solutions. The GCaMP3 calcium indicator is excited at $470 \mathrm{~nm}$, and its fluorescence emission collected at 525/50 nm using a $20 \times$ (NA 1) waterdipping objective on an upright Zeiss microscope (Axio Examiner.Z1; Carl Zeiss). In one set of LMMP experiments cells were stimulated electrically by a single stimulus or a train of stimuli (where indicated; $300 \mu \mathrm{s}$, 20 pulses, $20 \mathrm{~Hz}$ ) via a focal stimulating electrode $(50 \mu \mathrm{m}$ diameter platinum wire) placed on an interganglionic fiber tract (postnatal) or group of cells (embryonic) adjacent to the imaging area. In a separate set of experiments, cells in LMMP preparations were stimulated chemically either by application of 1-dimethyl-4-phenylpiperazinium (DMPP) or nicotine (both Sigma-Aldrich; 20 s exposure). In some cases, at the end of the experiment, high $\mathrm{K}^{+}$solution was applied ( $10 \mathrm{~s}$ exposure). Changes in GCaMP3 fluorescence, which reflects the intracellular $\mathrm{Ca}^{2+}$ concentration $\left(\left[\mathrm{Ca}^{2+}\right]_{\mathrm{i}}\right)$, were recorded on a cooled CCD camera (PCO Sensicam-QE) using TILLVisION software (TILL Photonics). Each preparation was stimulated electrically or chemically and recorded (at a 2 $\mathrm{Hz}$ frame rate, $30 \mathrm{~ms}$ exposure per frame) two times, 10 min apart: first in control saline conditions and then again in the presence of antagonists following a $10 \mathrm{~min}$ drug wash-in period. Time controls for electrical and chemical stimulation were performed whereby the preparations were stimulated twice, 10 min apart, in control saline conditions.

Following live-imaging experiments, selected preparations were fixed in $4 \%$ formaldehyde in $0.1 \mathrm{~m}$ phosphate buffer and immunostained using antisera to the pan-neuronal marker, $\mathrm{HuC} / \mathrm{HuD}$ (mouse, 1:500; Invitrogen) and the glial marker, $S 100 \beta$ (rabbit, 1:500; Sigma-Aldrich). Secondary antisera used were donkey anti-mouse Alexa 594 (1:1000; Invitrogen) and donkey anti-rabbit Alexa 647 (1:400; Invitrogen). 
Data analysis and statistics. All analyses were performed using customwritten macros in IGOR Pro (WaveMetrics). Regions of interest were drawn over an area of the cytoplasm of each cell excluding the nucleus (there is no GCaMP3 expression in the nuclei of cells), and fluorescence intensity was calculated and expressed as a fraction of the baseline fluorescence, $F_{i} / F_{o}$. Peaks in $\left[\mathrm{Ca}^{2+}\right]_{\mathrm{i}}$ (calcium transients) were individually defined and considered only if the signal had a minimum increase of five or three (for single pulse-stimulated responses) times the intrinsic noise. The amplitudes of calcium transients were measured as the maximum increase in $\left[\mathrm{Ca}^{2+}\right]_{\mathrm{i}}$ above baseline $\left(\Delta F_{i} / F_{o}\right)$.

In each experiment, the LMMP preparations were exposed to one antagonist, or a combination of antagonists, only once. The effects of each antagonist, or combination of antagonists, were examined in three to six mice and " $n$ " represents the total number of cells examined. For time controls, the $\Delta F_{i} / F_{o}$ of the second stimulation was calculated as a fraction of the first. The $\Delta F_{i} / F_{o}$ evoked in the presence of antagonists was normalized to the corresponding control conditions. All results are presented as mean percentage $\Delta F_{i} / F_{o}$ of the control \pm SEM. Statistical comparisons between time controls and antagonist conditions were performed using one-way ANOVA with Dunnett's post hoc test. $P$ values of $<0.05$ were considered to be significant.

Drugs used. Hexamethonium bromide, nicotine, DMPP, nifedipine (all from Sigma-Aldrich), methyllycaconitine citrate (MLA), dihydro- $\beta$ erythroidine (DH $\beta E$ ), SR16583 (SR, dissolved in DMSO), and $\alpha$-conotoxin MII (MII; all from Tocris Bioscience) were prepared as stock solutions dissolved in water (unless otherwise stated). All drugs were diluted in physiological saline before supplying the organ bath.

The final concentrations of MLA ( $50 \mathrm{~nm}, \alpha 7$ antagonist; Alkondon et al., 1992), DH $\beta \mathrm{E}(5 \mu \mathrm{M}, \alpha 4 \beta 2$ antagonist; Karadsheh et al., 2004; Takarada et al., 2012), SR (20 $\mu \mathrm{M}, \alpha 3 \beta 4$ antagonist; Zaveri et al., 2010), and MII (200 nм, $\alpha 3 \beta 2$ antagonist; Cartier et al., 1996) used in the present study are well above their $\mathrm{IC}_{50}$ values, but are within the previously reported ranges of specificity for their relevant nAChR subtypes. Although there is some evidence for MLA acting on $\alpha 4 \beta 2$ receptors at low nanomolar concentrations (Karadsheh et al., 2004), an effect of DH $\beta E$, but not MLA, observed in this study suggests little effect of MLA on $\alpha 4 \beta 2$ nAChRs. Furthermore, similar concentrations of MLA and MII have been used previously to examine contributions of $\alpha 7$ and $\alpha 3 \beta 2 \mathrm{nAChRs}$ in the guinea pig ENS (Obaid et al., 2005).

\section{Catenary (suspension) organ culture}

Migration and neuronal differentiation of ENCCs from E11.5 Ednrb ${ }^{K i k G R}$ or ChAT-Cre;R26R-YFP mice were assayed as described previously (Hearn et al., 1999; Anderson et al., 2006). In brief, explants of E11.5 gut (midgut plus hindgut) were dissected and mounted across "V" cut in filter paper supports. The explants were grown for $48 \mathrm{~h}$ in Terasaki wells containing $20 \mu \mathrm{l}$ of culture medium alone (DMEM/F12 with $20 \mathrm{mM} \mathrm{L-glutamine,} 6 \mathrm{mg} \mathrm{ml}^{-1}$ penicillin/streptomycin, and $10 \%$ fetal bovine serum) or culture medium containing hexamethonium $(200 \mu \mathrm{M})$.

Immunohistochemistry. After $48 \mathrm{~h}$ in culture, explants were fixed in $4 \%$ formaldehyde in $0.1 \mathrm{M}$ phosphate buffer. Explants of ChAT-Cre;R26RYFP mice were immunostained for the pan-neuronal marker $\mathrm{HuC} / \mathrm{D}$ (human, 1:5000; gift from Dr. V. Lennon), green fluorescent protein (goat, 1:400; Rockland), and neuronal nitric oxide synthase (sheep, 1:1000; gift from Dr. P. Emson). Secondary antisera used were as follows: donkey anti-human Alexa 594 (1:500; Jackson ImmunoResearch), donkey anti-rabbit FITC (1:200), and donkey anti-sheep Alexa 647 (1:500; Invitrogen).

Migration analysis. Images of the $E d n r b^{k i k}$ explants were taken using $5 \times$ objectives on a Zeiss Pascal confocal laser microscope. The distance migrated by KikGR-expressing ENCCs during the $48 \mathrm{~h}$ culture was determined by measuring the distance between the ileocecal junction and the most caudal ENCC in the postcecal hindgut (Anderson et al., 2006). Measurements were made using ImageJ software (NIH).

Neuron differentiation and density analysis. Images of ENCCs in two adjacent regions in the midgut of ChAT-Cre;R26R-YFP explants were taken using a $40 \times$ (NA 1.3) objective lens on a Zeiss Pascal confocal (pinhole size $72 \mu \mathrm{m}$ ) laser microscope. The number of $\mathrm{HuC} / \mathrm{D}+, \mathrm{GFP}+$, and nNOS + were counted, and the proportion all $\mathrm{Hu}+$ neurons that were GFP + and/or nNOS+ were determined. Neuronal density was determined by counting the total number of $\mathrm{Hu}+$ neurons per $\mathrm{mm}^{2}$. All results are presented as mean \pm SEM.

\section{Neurite outgrowth assay}

Whole intestines of E14.5 C57Bl embryos were dissected and dissociated in $0.1 \%$ trypsin/EDTA (Invitrogen) at $37^{\circ} \mathrm{C}$ for $20 \mathrm{~min}$, with gentle pipetting and straining through a $40 \mu \mathrm{m}$ filter as previously described (Hotta et al., 2013). Cells were resuspended in culture medium [DMEM/ F12 with $20 \mathrm{~mm}$ GlutaMAX (Invitrogen), $6 \mathrm{mg} \mathrm{ml}^{-1}$ penicillin/streptomycin, and $10 \%$ fetal bovine serum] and plated in a $200 \mu \mathrm{l}$ drop onto round glass coverslips in a 12-well plate at a concentration of $4 \times 10^{5}$ cells per well for a period of $3 \mathrm{~h}$ at $37^{\circ} \mathrm{C}$. The media was then changed to fresh culture medium or medium containing hexamethonium $(200 \mu \mathrm{M})$ or DMPP $(10 \mu \mathrm{M})$. After a further $9 \mathrm{~h}$ culture, the cells were fixed in $4 \%$ formaldehyde in $0.1 \mathrm{M}$ phosphate buffer and then immunostained for the pan-neuronal marker Tuj1 (mouse, 1:2000; Covance), followed by donkey anti-mouse Alexa 594 (1:200; Molecular Probes). Preparations were imaged using $10 \times$ objectives on an upright Zeiss microscope. The proportion of the total number of Tuj1 + cells that possessed one or more neurites that was greater in length than $50 \%$ of the diameter of the cell body was determined.

\section{Results}

Expression of $n A C h R$ subtypes in the fetal and postnatal gut We focused on $\alpha 3, \alpha 4, \alpha 7, \beta 2$, and $\beta 4 \mathrm{nAChR}$ subunits because they have previously been reported to be expressed by the ENS (Kirchgessner and Liu, 1998; Obaid et al., 2005; Garza et al., 2009) and because drugs are available that block the activity of these subunits. Quantitative expression of the genes encoding $\alpha 3-, \alpha 4-$, $\alpha 7-, \beta 2-$, and $\beta 4$-subunits was assessed using Droplet Digital PCR, which measures absolute concentration of transcripts. Gene expression was quantified in E11.5 and E14.5 whole intestines and in P0, P10, and adult myenteric plexus/external muscle preparations. All five transcripts were expressed at low levels in the E11.5 gut, and were upregulated by E14.5 with $\alpha 3$ and $\beta 4$ transcripts showing the highest concentrations at E14.5 (Fig. 1A). Also postnatally, $\alpha 3$ and $\beta 4$ were the most abundant transcripts, and there were no significant changes in the concentrations of any of the transcripts in myenteric plexus/external muscle preparations among P0, P10, and adult (Fig. 1B).

\section{Functional expression of specific $\mathrm{nAChR}$ subtypes using live $\mathrm{Ca}^{2+}$ imaging}

$\mathrm{Ca}^{2+}$-imaging experiments were conducted on duodenal myenteric plexus preparations of adult (12 animals), P10-P11 (15 animals), and P0 (20 animals) Wnt1-Cre;R26R-GCaMP3 mice. The proximal small intestine of E14.5 (21 animals) and E12.5 (18 animals) and the proximal colon of E12.5 (11 animals) Wnt1-Cre; R26R-GCaMP3 mice were examined.

Adult myenteric neurons express $\alpha 3, \alpha 4, \beta 2$, and $\beta 4 n A C h R$ subtypes that mediate DMPP-evoked and single pulse-evoked $\left[\mathrm{Ca}^{2+}\right]_{i}$ transients

Electrical stimulation of interganglionic fiber tracts and application of the general nAChR agonist, DMPP $(10 \mu \mathrm{M})$, induced a sharp increase in $\left[\mathrm{Ca}^{2+}\right]_{\mathrm{i}}$ in adult myenteric neurons (Fig. 2). As reported previously, neurons typically respond instantly to these stimuli, while glial cells have delayed responses (Boesmans et al., 2013). The DMPP response was almost abolished by the general nAChR antagonist, hexamethonium (200 $\mu \mathrm{M} ; n=53$; Fig. $2 B)$. Additionally, a single-pulse stimulus was applied as this stimulus regime is typically used to evoke fast and intermediate EPSPs, notably the former. The response to a single-pulse electrical stimulus was significantly reduced by hexamethonium ( $n=40$; Fig. $2 C$ ) but not abolished. This is consistent with the report of other fast excitatory 

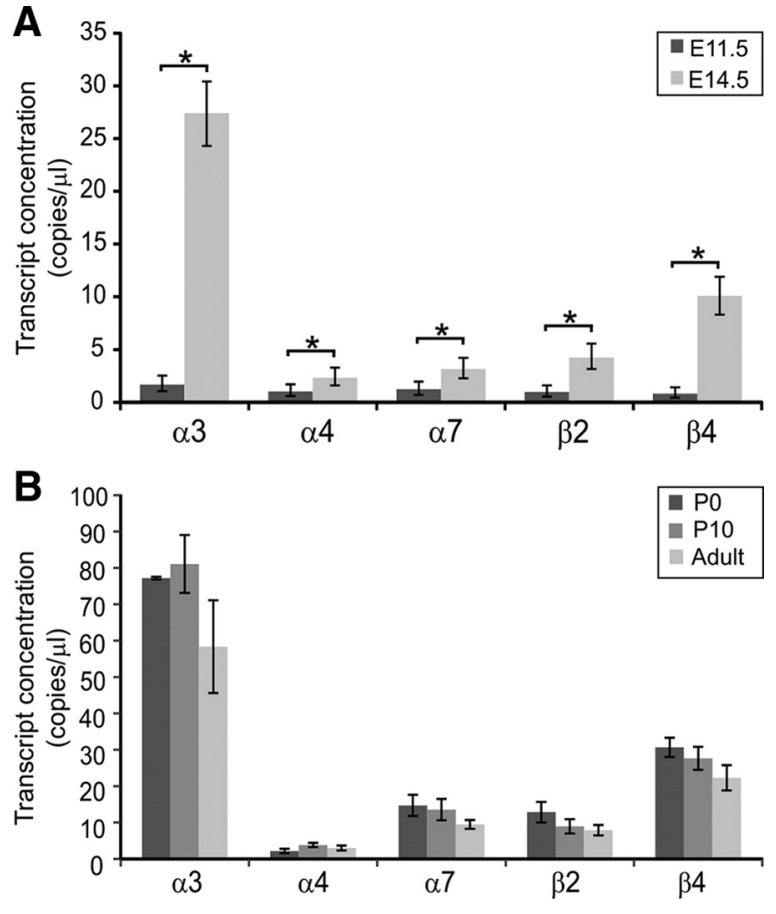

Figure 1. Quantitative expression of genes encoding $\alpha 3-, \alpha 4-, \alpha 7-, \beta 2-$, and $\beta 4$-subunits in the gut at different ages. Transcripts encoding $\alpha 3, \alpha 4, \alpha 7, \beta 2$, and $\beta 4$ were quantified in $\mathrm{E} 11.5$ and E14.5 whole intestines and in P0, P10, and adult myenteric plexus/external muscle preparations using Droplet Digital PCR. A, All five transcripts were expressed at low levels in the E11.5 gut and were significantly upregulated between E11.5 and E14.5 ( $\chi^{2}$ tests, ${ }^{*} p<0.05$ ). The transcripts present at the highest concentrations at E14.5 were $\alpha 3$ and $\beta 4$. No DNA template and no reverse transcriptase. Controls were performed with every assay, and in all cases, revealed 0 transcripts. Data show RNA extracted from pooled $20 \times$ E11.5 and $4 \times$ E14.5 small and large intestines. Error bars represent $95 \%$ Poisson confidence limits. $\boldsymbol{B}$, There were no significant changes in the concentrations of any of the transcripts in myenteric plexus/external muscle preparations among $\mathrm{PO}, \mathrm{P} 10$, and adult (mean $\pm \mathrm{SEM}, n=2$ for each age, one-way ANOVAs, $p<0.05)$. As whole gut was used at E11.5 and E14.5 and myenteric plexus/external muscle preparations postnatally, the prenatal $(\boldsymbol{A})$ and postnatal $(\boldsymbol{B})$ data cannot be directly compared. Concentration is represented as copies of transcript per microliter of amplified PCR mixture. Droplet Digital PCR measures absolute concentrations of transcripts; hence, standard curves and internal reference genes are not required.

neurotransmitters, such as ATP, in the mouse ENS (Nurgali et al., 2004). Alternatively, the remaining hexamethonium-resistant response could be the result of direct antidromic nonsynaptic neuronal activation (Martens et al., 2014).

Antagonists targeting $\alpha 3 \beta 2, \alpha 3 \beta 4, \alpha 7$, and $\alpha 4 \beta 2$ nAChRs were used to examine the receptor subtypes involved in the adult mouse ENS. Both single-pulse stimulation and DMPP evoked an increase in $\left[\mathrm{Ca}^{2+}\right]_{\mathrm{i}}$ that was significantly reduced by MII $(\alpha 3 \beta 2$ antagonist, $200 \mathrm{nM}$; single pulse: $n=40$, DMPP: $n=34)$, SR ( $\alpha 3 \beta 4$ antagonist, $20 \mu \mathrm{M}$; single pulse: $n=59$, DMPP: $n=47$ ), and $\mathrm{DH} \beta \mathrm{E}$ ( $\alpha 4 \beta 2$ antagonist, $5 \mu \mathrm{M}$; single pulse: $n=40$, DMPP: $n=55$; Fig. 2). When applied together, these three antagonists produced a greater effect on the DMPP response than any one alone. However, there was still a residual response ( $49 \pm 2 \%$ of the control, $n=65$ ) in the presence of the three antagonists combined, which was larger than the hexamethoniuminsensitive response ( $13 \pm 2 \%$ of the control; Fig. $2 B)$. This shows that other nAChR subtypes are likely to be involved in mediating the response to DMPP.

MLA ( $\alpha 7$ antagonist, $50 \mathrm{nM}$ ) did not have a significant effect on the single-pulse or DMPP-evoked responses of adult neurons (single pulse: $n=31$, DMPP: $n=39$; Fig. 2). Trains of stimuli were also applied to interganglionic fiber tracts; such trains evoke slow synaptic potentials due to release of transmitters other than $\mathrm{ACh}$ and fast cholinergic synaptic potentials that decline in amplitude during the train. The only nAChR antagonists tested that had significant effects on the increase in $\left[\mathrm{Ca}^{2+}\right]_{\mathrm{i}}$ evoked by trains of stimuli were MLA and SR (MLA: $70 \pm 6 \%$ of control, $n=46$; SR: $59 \pm 7 \%$ of control, $n=35$; records not illustrated). This indicated that responses to trains of stimuli were pharmacologically too complex and not appropriate to analyze the development of nAChR subtypes; therefore, these responses were not systematically analyzed at younger ages.

Alterations in $n A C h R$ subtype involvement between birth and $P 10$ Both neurons (marked by immunoreactivity for $\mathrm{HuC} / \mathrm{D}$ ) and glia (marked by $\mathrm{S} 100 \beta$ ) of early postnatal mice expressed GCaMP3 (Fig. 3A), as previously described in the adult Wnt1-Cre;R26RGCaMP3 myenteric plexus (Boesmans et al., 2013). Electrical stimulation of interganglionic fiber tracts and DMPP $(10 \mu \mathrm{M})$ application induced a sharp increase in $\left[\mathrm{Ca}^{2+}\right]_{\mathrm{i}}$ in P0 and P10P11 myenteric neurons (Fig. 3 F, I). Post hoc immunohistochemistry confirmed that the vast majority of the responding cells were neurons as they were labeled with a $\mathrm{HuC} / \mathrm{D}$ antibody (data not shown). As in adults, hexamethonium $(200 \mu \mathrm{M})$ almost abolished the DMPP-evoked response (P10-P11: $n=52$, P0: $n=84)$ and significantly reduced the single pulse-evoked response at $\mathrm{P} 0$ and P10-P11 (P10-P11: $n=23, \mathrm{P} 0: n=69$; Fig. 3D-I).

At P10-P11, the DMPP-evoked increase in $\left[\mathrm{Ca}^{2+}\right]_{\mathrm{i}}$ was significantly reduced by both SR ( $\alpha 3 \beta 4$ antagonist, $20 \mu \mathrm{M} ; n=83$ ) and $\mathrm{DH} \beta \mathrm{E}(\alpha 4 \beta 2$ antagonist, $5 \mu \mathrm{M} ; n=67)$. The MII compound ( $\alpha 3 \beta 2$ antagonist, $200 \mathrm{nM} ; n=48$ ) reduced the DMPP response, but this was not significant (Fig. $3 D$ ). The single pulse-evoked response was, however, significantly reduced by MII $(n=24)$, SR $(n=41)$ and $\mathrm{DH} \beta \mathrm{E}(n=42$; Fig. $3 G)$. MLA ( $\alpha 7$ antagonist, 50 $\mathrm{nM})$ did not have a significant effect on DMPP responses $(n=53$; Fig. $3 D$ ), but significantly reduced the single-pulse responses $(n=39$; Fig. $3 G)$. Thus, the nAChR subtypes involved in the responses at $\mathrm{P} 10-\mathrm{P} 11$ are very similar to those in the adult.

At P0, the only nAChR subtype antagonist that had a significant effect on DMPP-evoked and single pulse-evoked increases in $\left[\mathrm{Ca}^{2+}\right]_{\mathrm{i}}$ was the SR compound ( $\alpha 3 \beta 4$ antagonist, $20 \mu \mathrm{M}$; DMPP: $n=83$; single pulse: $n=51$; Fig. $3 E, H$ ). Therefore the subtypes that mediate $\mathrm{nAChR}$ responses at $\mathrm{P} 0$ are less diverse than those involved in P10-P11 and adult myenteric plexus.

\section{Nicotinic receptors are present by E12.5, including unconventional receptors that are insensitive to hexamethonium}

The proximal small intestine from E14.5 mice was cut along the mesenteric border and pinned (serosal side up) at the oral and anal ends in the organ bath. Application of DMPP (10 $\mu \mathrm{M})$ produced a large contraction, and the resulting distortion of the gut prevented the cell-specific analysis of any changes in $\left[\mathrm{Ca}^{2+}\right]_{i}$. Accordingly, only single pulse-evoked responses were examined at E14.5. At this age, a single-pulse electrical stimulus applied to the oral end of the tissue evoked a sharp increase in $\left[\mathrm{Ca}^{2+}\right]_{\mathrm{i}}$ (Fig. $4 A, D)$. Hexamethonium $(200 \mu \mathrm{M})$ significantly reduced this response $(n=58)$ as seen in postnatal neurons. However, the only $\mathrm{nAChR}$ subtype-specific antagonist that had a significant effect at E14.5 was the $\alpha 3 \beta 4$ antagonist (SR, $20 \mu \mathrm{M} ; n=68$; Fig. $4 D$ ), similar to what was seen at P0.

At E12.5, the proximal small intestine was examined as an intact tube. As reported previously by E11.5 cultured ENCCs (Hao et al., 2011), spontaneous $\left[\mathrm{Ca}^{2+}\right]_{\mathrm{i}}$ transients were fre- 

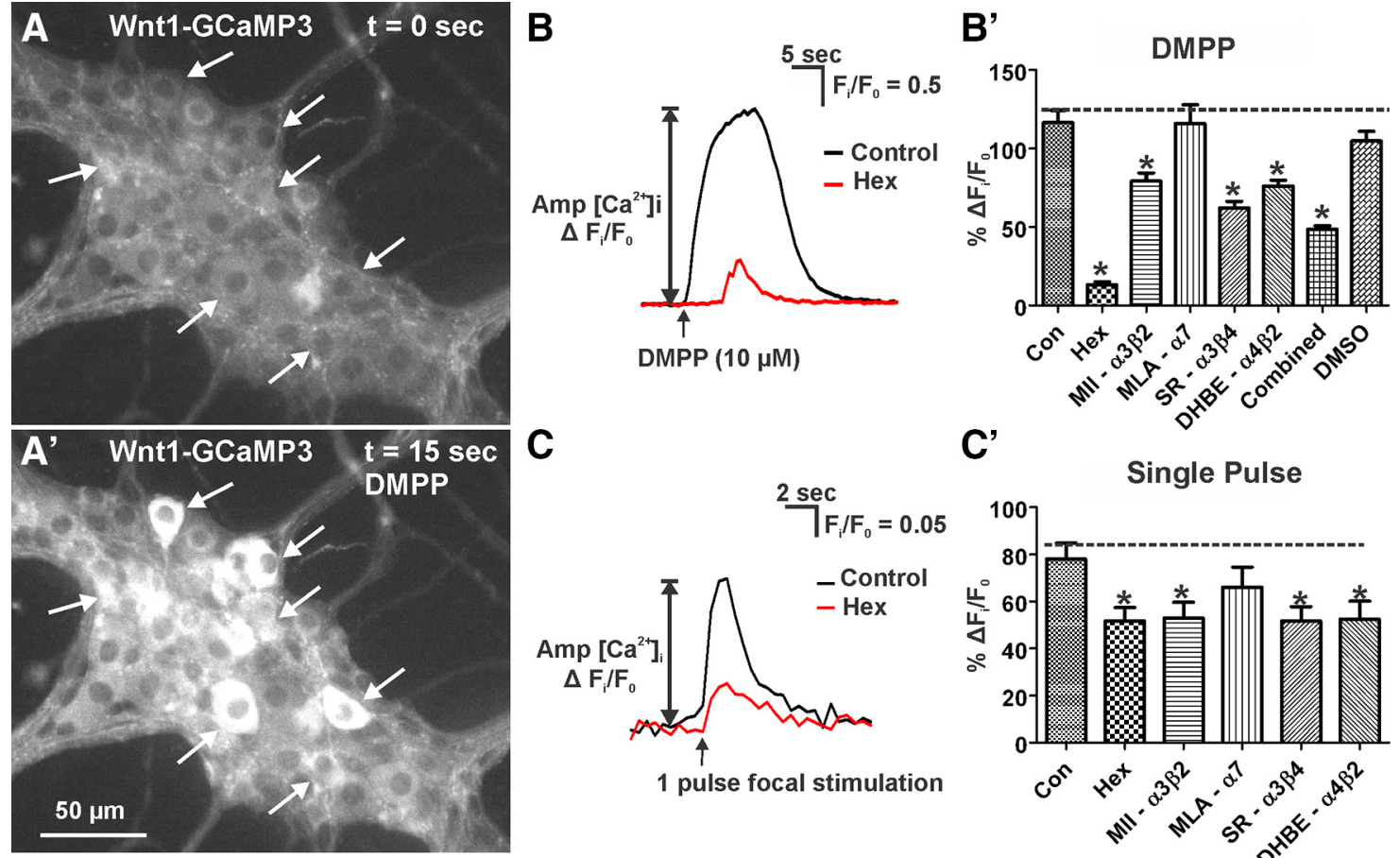

C'
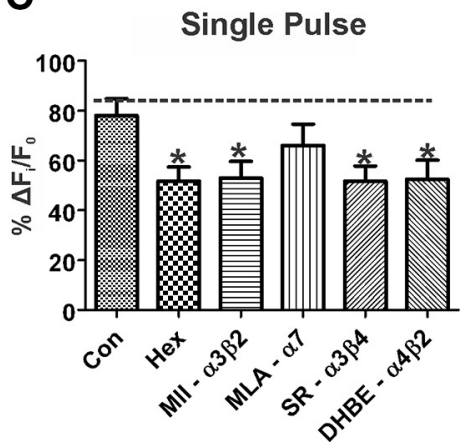

Figure 2. Effect of $n A C h R$ subtype antagonists on DMPP and single pulse-evoked $\left[\mathrm{Ca}^{2+}\right]_{\mathrm{i}}$ transients in myenteric neurons of the adult duodenum. $A$, Representative fluorescence micrographs of the DMPP $(10 \mu \mathrm{M})$-evoked $\left[\mathrm{Ca}^{2+}\right]_{\mathrm{i}}$ response in myenteric neurons [GCaMP3 signal at rest $(\boldsymbol{A}, t=0)$; and during DMPP stimulation $(\boldsymbol{A}, t=15 \mathrm{~s})$ ]. Most neurons responded to DMPP (some responsive neurons marked by arrows). Example traces from a single cell of DMPP $(\boldsymbol{B})$ and single pulse ( $\boldsymbol{C}$-evoked changes in $\left[\mathrm{Ca}^{2+}\right]_{\mathrm{i}}$ in control conditions (black trace) and in the presence of hexamethonium (Hex; red trace). Cells were stimulated twice, first in the presence of control saline, and second after $10 \mathrm{~min}$ application of antagonists. $\boldsymbol{B}^{\prime}, \boldsymbol{C}^{\prime}$, Histograms summarizing the pooled dataset from all cells stimulated with $\operatorname{DMPP}\left(\boldsymbol{B}^{\prime}\right)$ or a single pulse $\left(\boldsymbol{C}^{\prime}\right)$. Changes in amplitude after application of $\mathrm{nAChR}$ antagonists are presented as a percentage of the first response in control saline. Time controls were also performed (Con) where both stimuli were executed in control saline, 10 min apart. Hexamethonium $(200 \mu \mathrm{M})$, $\mathrm{MII}(200 \mathrm{nM}), \mathrm{SR}(20 \mu \mathrm{M})$, and DH $\beta E(5 \mu \mathrm{M})$ significantly reduced the $\left[\mathrm{Ca}^{2+}\right]_{\mathrm{i}}$ response evoked by DMPP $\left(\boldsymbol{B}^{\prime}\right)$ and single-pulse stimulation $\left(\boldsymbol{C}^{\prime}\right) \cdot \boldsymbol{B}^{\prime}, \mathrm{MLA}(50 \mathrm{nM})$ and DMSO did not affect DMPP-evoked $\left[\mathrm{Ca}^{2+}\right]_{\mathrm{i}}$ responses. The combined addition of MII, SR, and DH $\beta E$ (Combined) produced a greater effect on DMPP-evoked responses than the application of each antagonist on its own. $C^{\prime}$, MLA also did not significantly affect the single pulse-evoked $\left[\mathrm{Ca}^{2+}\right]_{\mathrm{i}}$ response.

quently exhibited by E12.5 ENCCs in intact preparations. This prevented the examination of single pulse-evoked responses. Therefore, only responses to DMPP application were examined at E12.5. DMPP $(10 \mu \mathrm{M})$ evoked a sharp increase in $\left[\mathrm{Ca}^{2+}\right]_{\mathrm{i}}$ in many ENCCs (Fig. $4 E$ ), some of which had long axon-like processes (Fig. $4 B^{\prime}$ ). Similar groups of cells that responded to DMPP also responded to $75 \mathrm{mM} \mathrm{K}^{+}$(Fig. $4 B$ ), a stimulus typically used to identify neurons (Boesmans et al., 2013). As $\alpha 3 \beta 4 \mathrm{nAChRs}$ are involved in responses at $\mathrm{E} 14.5$ and $\mathrm{P} 0$, the SR compound was also examined at E12.5. The DMPP response was significantly reduced by SR ( $20 \mu \mathrm{M} ; n=69$; Fig. $4 E)$. While there was no significant contribution of $\alpha 7 \mathrm{nAChRs}$ to the responses examined at E14.5 and older, $\alpha 7$ homopentamers have been reported to be involved during development of other parts of the nervous system (Liu et al., 2007). Therefore, the antagonist for this receptor subtype, MLA (50 nM), was also examined at E12.5, but had no significant effect on responses to DMPP $(n=48$; Fig. $4 E)$.

Unlike responses at older ages, hexamethonium $(200 \mu \mathrm{M})$ did not abolish the DMPP-evoked response of ENCCs in the E12.5 small intestine leaving a substantial residual component (40 \pm $2 \%$ of the control, $n=72$; Fig. $4 E$ ). To determine whether there are unconventional receptors insensitive to hexamethonium at early stages of development, the E12.5 colon was also examined; the ENS matures in a rostral-to-caudal fashion, so colonic ENCCs might be expected to exhibit an even more immature phenotype. Application of DMPP $(10 \mu \mathrm{M})$ to the E12.5 colon evoked increases in $\left[\mathrm{Ca}^{2+}\right]_{\mathrm{i}}$ that were completely insensitive to hexamethonium ( $n=42$; Fig. $4 C, F)$. The responses to DMPP and $75 \mathrm{mM} \mathrm{K}^{+}$exhibited by ENCCs in the colon were smaller than those in the small intestine (Fig. $4 B, C, G$ ). To confirm the nicotinic nature of these responses, we also applied nicotine (1 $\mu \mathrm{M}$, E12.5 colon) itself, which indeed evoked similar $\left[\mathrm{Ca}^{2+}\right]_{\mathrm{i}}$ increases. Although the nicotine-evoked response was significantly reduced by hexamethonium, a large residual component was hexamethonium insensitive ( $68 \pm 4 \%$ of the control, $n=37$; Fig. $4 F$ ). In summary, like P0s, the $\alpha 3 \beta 4 \mathrm{nAChRs}$ mediated single pulse-evoked and DMPP-evoked changes in $\left[\mathrm{Ca}^{2+}\right]_{\mathrm{i}}$ at E14.5 and E12.5. In addition, there appear to be unconventional nicotinic receptors that are insensitive to hexamethonium earlier in development.

Nicotinic receptors do not regulate migration, differentiation, or neurite outgrowth in the embryonic ENS

Recent studies have shown that early developing enteric neurons influence the development of neurons that are generated later ( $\mathrm{Li}$ et al., 2010, 2011; Hao et al., 2013b). We performed assays for ENCC migration, neuronal differentiation (Hearn et al., 1999; Anderson et al., 2006), and neuritogenesis to examine the effects of hexamethonium $(200 \mu \mathrm{M})$ and DMPP $(10 \mu \mathrm{M}$, for neuritogenesis only; Fig. 5). Two major ENS subtypes are ChAT and nNOS neurons. We therefore examined the differentiation of these two neuronal subtypes using ChAT-Cre;R26R-YFP mice, where the vast majority of ChAT-immunoreactive neurons express YFP (Hao et al., 2013a; Erickson et al., 2014; Foong et al., 2014). Hexamethonium did not have any effect on the acquisition of YFP (thus ChAT) or nNOS neurochemical phenotypes (Fig. $5 B$ ), or the density of $\mathrm{HuC} / \mathrm{D}+$ cells (Fig. $5 \mathrm{C}$ ). The rate of migration of ENCCs in gut explants (Fig. 5E) and the proportion of Tuj1+ 

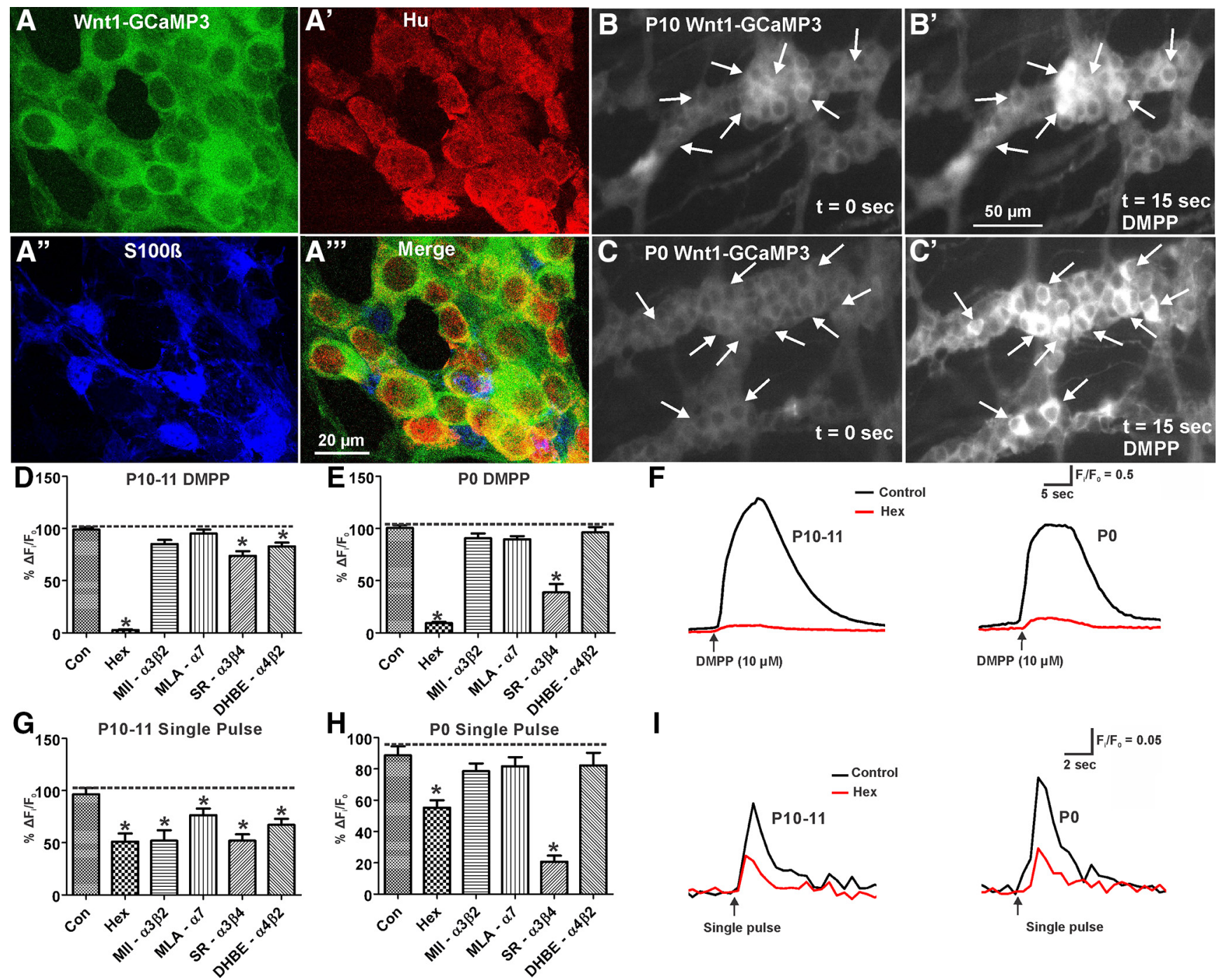

Figure 3. Effect of $n A C h R$ subtype antagonists on DMPP and single pulse-evoked $\left[\mathrm{Ca}^{2+}\right]_{i}$ transients in myenteric neurons of the early postnatal duodenum. $A$, Confocal micrographs of a P10 LMMP preparation that expressed GCaMP3 (green, $\boldsymbol{A}$ ) fluorescence and immunostained for $\mathrm{Hu}\left(\right.$ red, $\boldsymbol{A}^{\prime}$ ) and $\mathrm{S} 100 \beta$ (blue, $\left.\boldsymbol{A}^{\prime \prime}\right)$. Merged color image is in $\boldsymbol{A}^{\prime \prime \prime}$. Representative grayscale fluorescence micrographs of the DMPP $(10 \mu \mathrm{M})$-evoked $\left[\mathrm{Ca}^{2+}\right]_{\mathrm{i}}$ response in P10 (B) and PO (C) myenteric neurons. Most neurons responded to DMPP (some responsive neurons marked by arrows). $\boldsymbol{D}, \boldsymbol{E}, \boldsymbol{G}, \boldsymbol{H}$, Histograms summarizing the pooled dataset of the amplitude of DMPP-evoked $(\boldsymbol{D}, \boldsymbol{E})$ and single pulse-evoked $(\boldsymbol{G}, \boldsymbol{H})\left[\mathrm{Ca}^{2+}\right]_{\mathrm{i}}$ responses presented as a fraction of the first control saline responses to DMPP addition or single-pulse stimulation, respectively. Changes in $\left[\mathrm{Ca}^{2+}\right]_{\mathrm{i}}$ responses in the presence of different nAChR antagonists were compared with time controls (Con). At P10 -P11, hexamethonium $(\mathrm{Hex} ; 200 \mu \mathrm{M}), \operatorname{SR}(20 \mu \mathrm{M})$, and DH $\beta E(5 \mu \mathrm{M})$ significantly reduced the $\left[\mathrm{Ca}^{2+}\right]_{\text {i }}$ responses evoked by DMPP $(\boldsymbol{D})$ and single-pulse stimulation $(\boldsymbol{G})$. D, Although MII (200 nM) reduced DMPP-evoked responses, this effect was not significant. $G$, Nonetheless, the MII compound significantly reduced single pulse-evoked $\left[\mathrm{Ca}^{2+}\right]_{\mathrm{i}}$ responses. MLA (50 nM) did not affect DMPP-evoked responses $(\boldsymbol{D})$ but significantly reduced single pulse-evoked $(\boldsymbol{G})\left[\mathrm{Ca}^{2+}\right]_{\mathrm{i}}$ responses. At PO, only hexamethonium and SR significantly reduced DMPP $(\boldsymbol{E})$ and single pulse-evoked $(\boldsymbol{H})\left[\mathrm{Ca}^{2+}\right]_{\mathrm{i}}$ responses. Example traces from a single cell of DMPP $(\boldsymbol{F})$ and single pulse $(\boldsymbol{I})$-evoked change in $\left[\mathrm{Ca}^{2+}\right]_{\mathrm{i}}$ in control conditions and in the presence of hexamethonium (red).

cells extending neurites in dissociated, cultured ENCCs (Fig. $5 F$ ) were also unaffected by hexamethonium. DMPP also did not affect neurite outgrowth (Fig. $5 F$ ). Thus, despite the presence of cholinergic neurons early in ENS development (Erickson et al., 2014) and of functional nicotinic receptors, we were unable to detect roles for cholinergic neurons in ENCC migration, neuronal differentiation, or neurite extension at least during early (E11.5-E14.5) stages of enteric neural development.

\section{Discussion}

Cholinergic communication via nicotinic receptors is an essential mode of synaptic transmission in the mature ENS, but the roles of these receptors and their subunit compositions during ENS development have been elusive. In this study, we showed that nAChR subtype transcripts expressed in the adult ENS are already present by E11.5. However, only $\alpha 3 \beta 4 \mathrm{nAChRs}$ were found to mediate responses at, and before, birth; consistent with this, the concentrations of $\alpha 3$ and $\beta 4$ transcripts in the E14.5 gut were higher than other nAChR transcripts examined. Moreover, we revealed potential unconventional nicotinic receptors that were insensitive to hexamethonium at E12.5. By P10, the nAChR subtypes $(\alpha 3 \beta 2, \alpha 3 \beta 4$, and $\alpha 4 \beta 2)$ that mediate chemically and electrically evoked increases in $\left[\mathrm{Ca}^{2+}\right]_{\mathrm{i}}$ were similar to those in the adult. Despite early expression of nAChRs, blockade of nAChRs with hexamethonium had no detectable effect on ENCC migration, neuronal differentiation, or neurite outgrowth during embryogenesis.

\section{Changes in nAChR subtypes during development}

Nicotinic receptors are well known to play prominent roles in the developing CNS. For example, spontaneous nicotinic excitation facilitates target selection and synapse formation in the CNS (Liu 

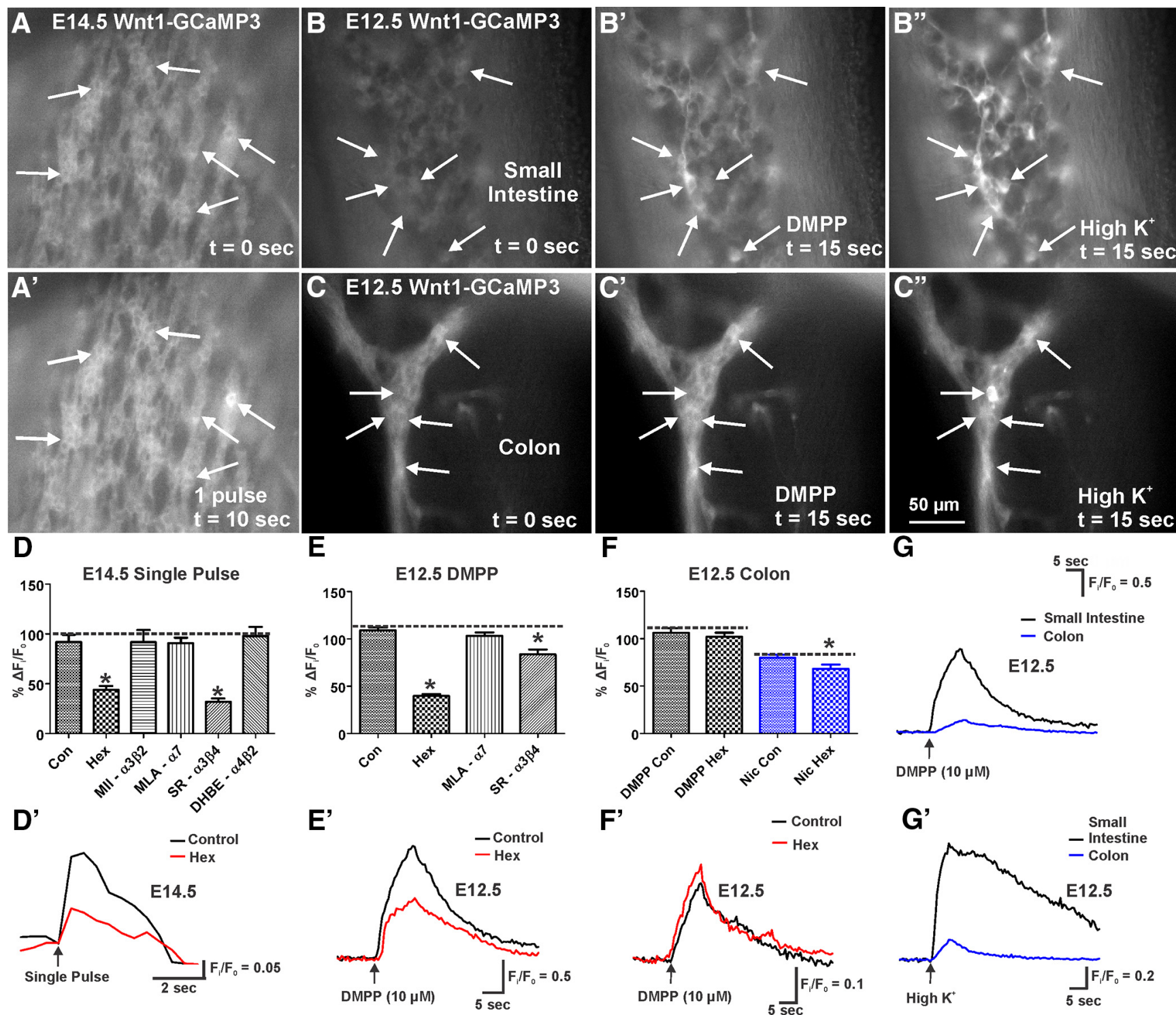

Figure 4. Effect of nAChR subtype antagonists on DMPP and single pulse-evoked $\left[\mathrm{Ca}^{2+}\right]_{\mathrm{i}}$ transients in myenteric neurons of E12.5 and E14.5 proximal small intestine, respectively. $\boldsymbol{A}$ Representative fluorescence micrographs of the single pulse-evoked $\left[\mathrm{Ca}^{2+}\right]_{\mathrm{i}}$ response at E14.5 [GCaMP3 signal at rest $(\boldsymbol{A}, t=0)$; and just after stimulation $\left.\left(\boldsymbol{A}^{\prime}, t=10 \mathrm{~s}\right)\right]$. Example fluorescence micrographs of DMPP $(10 \mu \mathrm{M})$ and high $\mathrm{K}^{+}(75 \mathrm{~mm})$-evoked $\left[\mathrm{Ca}^{2+}\right]_{\mathrm{i}}$ responses in the E12.5 proximal small intestine (GCaMP3 signal at rest, $\boldsymbol{B}$; during DMPP stimulation, $\boldsymbol{B}^{\prime}$; during high $\mathrm{K}^{+}$ depolarization, $\boldsymbol{B}^{\prime \prime}$ ) and colon (GCaMP3 signal at rest, $\boldsymbol{C}$; during DMPP stimulation, $\boldsymbol{C}^{\prime}$; during high $\mathrm{K}^{+}$depoloarization, $\boldsymbol{C}^{\prime \prime}$ ). Example of responding cells are marked by arrows (snapshots for high $\mathrm{K}^{+}$and DMPP recordings were taken from separate recordings). $\boldsymbol{D}-\boldsymbol{F}$, Histograms summarizing the pooled dataset. Amplitude of single pulse-evoked (D; at E14.5), DMPP-evoked (E; E12.5 small intestine), and DMPP/nicotine-evoked ( $\boldsymbol{F} ; \mathrm{E} 12.5$ colon) $\left[\mathrm{Ca}^{2+}\right]_{\mathrm{i}}$ responses presented as a fraction of the first responses to DMPP/nicotine or single-pulse stimulation, respectively. The first responses correspond to the responses evoked by stimulations elicited at the first time point for time controls (Con) or the responses evoked during control conditions for antagonist experiments. D, At E14.5, hexamethonium (Hex, $200 \mu \mathrm{m})$ and SR $(20 \mu \mathrm{m})$ significantly reduced the single pulse-evoked $\left[\mathrm{Ca}^{2+}\right]_{\mathrm{i}}$ response. $\boldsymbol{D}^{\prime}$, Example traces from a single cell of the single pulse-evoked change in $\left[\mathrm{Ca}^{2+}\right]_{\mathrm{i}}$ in control conditions and in the presence of hexamethonium (red). $\boldsymbol{E}$, In the E12.5 proximal small intestine, hexamethonium and SR also significantly reduced the DMPP-evoked [Ca $\left.{ }^{2+}\right]_{i}$ response. However, $40 \%$ of the DMPP response was not affected by hexamethonium. $F$, In the E12.5 colon, DMPP-evoked responses were unaffected by hexamethonium. Furthermore, $70 \%$ of the nicotine (Nic)-evoked increase in $\left[\mathrm{Ca}^{2+}\right]_{i}$ was also unaffected by hexamethonium. Example traces from a single cell of DMPP-evoked changes in $\left[\mathrm{Ca}^{2+}\right]_{i}$ in control conditions and in the presence of hexamethonium (red) from the E12.5 proximal small intestine $\left(\boldsymbol{E}^{\prime}\right)$ and colon $\left(\boldsymbol{F}^{\prime}\right)$. Example traces from a single cell of DMPP-evoked $(\boldsymbol{G})$ and high $\mathrm{K}^{+}\left(75 \mathrm{~mm} ; \boldsymbol{G}^{\prime}\right)$-evoked change in $\left[\mathrm{Ca}^{2+}\right]_{\mathrm{i}}$ exhibited by E12.5 small intestine and colon (blue).

et al., 2007). Moreover, activation of $\alpha 4 \beta 2 \mathrm{nAChRs}$ promotes neuronal differentiation in the neocortex of embryonic rats (Takarada et al., 2012), and $\alpha 7 \mathrm{nAChRs}$ mediate changes in chloride gradient associated with GABAergic signaling during late embryogenesis and early postnatal life (Liu et al., 2007).

In the developing ENS, neuronal activity is present early and influences the differentiation of ENCCs (Hao et al., 2010, 2013b; Li et al., 2011). Acetylcholine is an important neurotransmitter in the early postnatal and adult ENS (Gwynne and Bornstein, 2007; Foong et al., 2012); however, its role during development has not been previously investigated. The earliest report of nicotinic fEPSPs in the murine myenteric plexus was at birth (Foong et al., 2012), but it was unknown when functional cholinergic synapses first appear. Recent studies raised the possibility that nicotinic fast excitatory neurotransmission is one of the first forms of neuronal communication. ENCCs that express ChAT are present early in development (by E10.5; Erickson et al., 2014). Furthermore, cultured ENCCs from dissociated E11.5 respond to DMPP, and exhibit fEPSP-like events at E12.5 (Hao et al., 2011, 2012). 

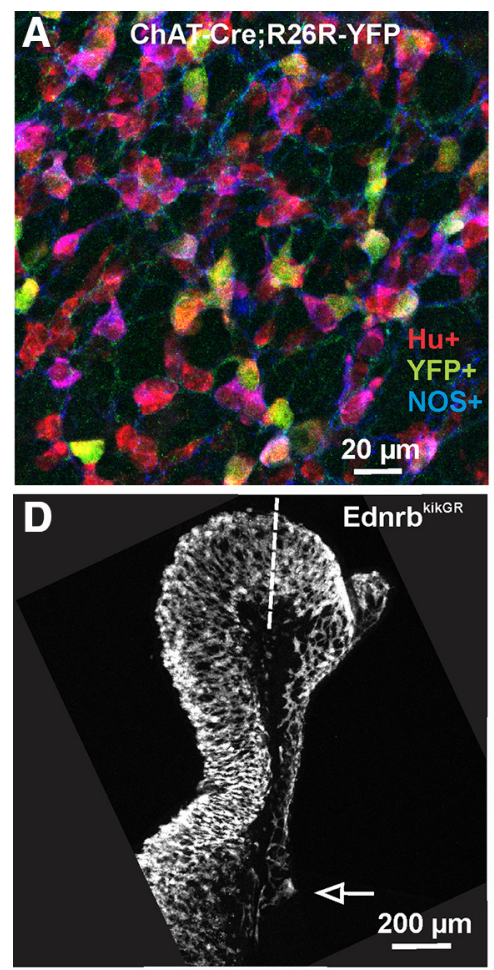

B

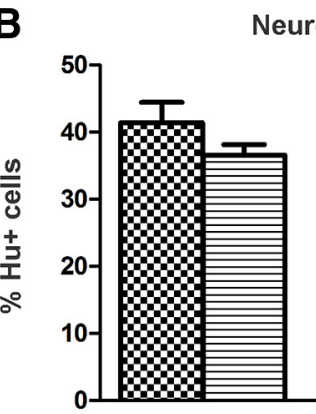

YFP+
Neuronal differentiation

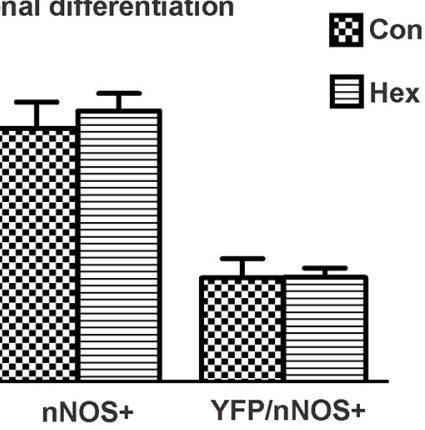

$E$

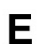

$\mathbf{F}$$$
\mathbf{F}
$$

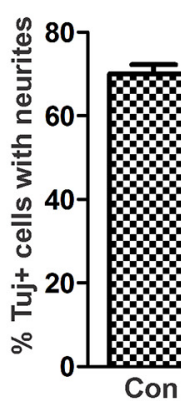

Neuritogenesis

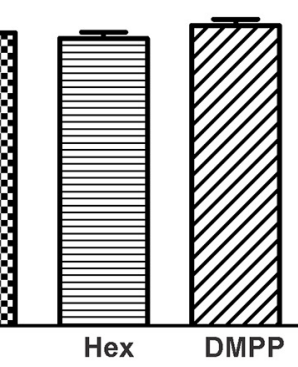

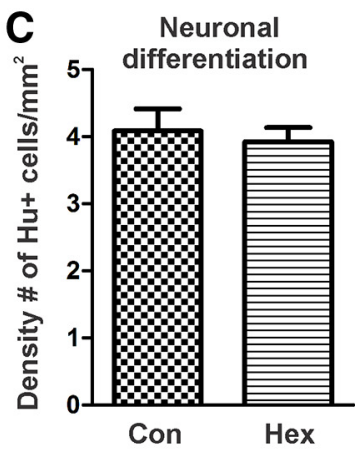
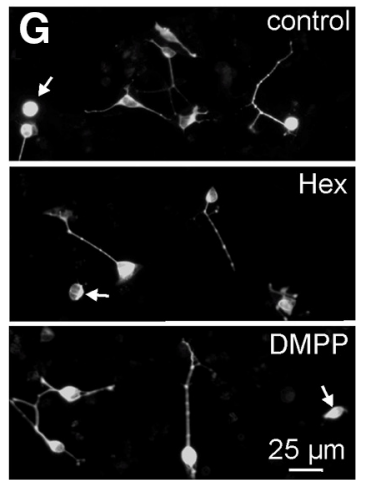

Figure 5. Role of nicotinic receptors in embryonic enteric neuron development. $A$, A single optical section from the midgut region of catenary cultures immunostained for Hu (red), YFP ( $g r e e n)$, and NOS (blue). $\boldsymbol{B}$, Proportion of Hu + cells that coexpressed YFP, NOS, or YFP and NOS in control conditions (Con) and in the presence of hexamethonium (Hex; $200 \mu \mathrm{m}$ ). Hexamethonium did not have a significant effect on the differentiation of YFP + or NOS + neurons. $C$, The density of $\mathrm{Hu}+$ cells per $\mathrm{mm}^{2}$ did not differ between gut explants cultured in control conditions and in the presence of hexamethonium. D, Explant of midgut and hindgut from E11.5 Ednrb ${ }^{\text {kik }}$ mice grown in culture for $48 \mathrm{~h}$. The distance from the ileocecal junction (dotted line) to the most caudal cell (open arrow) was measured as the migration distance of ENCCS $(\boldsymbol{E})$. $\boldsymbol{E}$, Hexamethonium did not affect migration of ENCCs. $\boldsymbol{F}$, Quantification of the proportion of Tuj1 + cells that exhibited neurites in the neurite outgrowth assay. Hexamethonium and DMPP $(10 \mu \mathrm{M})$ did not affect the proportion of Tuj1 + cells that projected neurites. G, Micrographs of dissociated E14.5 gut neurons immunostained using the pan-neuronal marker Tuj1 in control, or in the presence of hexamethonium or DMPP conditions. A similar proportion of Tuj1+ neurons lacked neurites (arrows) in all three conditions.

We found that, while nAChR transcripts expressed in the adult ENS are present at low levels by E11.5, the nAChR subtypes that mediate chemically and electrically evoked increases in $\left[\mathrm{Ca}^{2+}\right]_{\mathrm{i}}$ are less diverse during embryonic stages. Transcripts for $\alpha 3$ and $\beta 4 \mathrm{nAChRs}$ occurred at higher concentrations than other nAChR transcripts at E14.5, and $\alpha 3 \beta 4 \mathrm{nAChRs} \mathrm{were} \mathrm{the} \mathrm{major}$ contributors to responses examined at E12.5, E14.5, and P0. However, blockade of all nAChRs with hexamethonium did not affect ENCC migration, acquisition of ChAT and nNOS neurochemical phenotype, or density of $\mathrm{Hu}+$ neurons. Contrary to an invertebrate model system, in which activation of nAChRs elongates neuronal growth cone filopodia in the pond snail Helisoma trivolvis (Zhong et al., 2013), we did not find any significant effect of hexamethonium or DMPP on enteric neuritogenesis during embryonic stages. Nonetheless, we cannot rule out the possibility of nAChRs mediating other developmental processes, such as synaptogenesis, for which we currently do not have assays.

Substantial changes in functional nAChRs occurred between birth and P10 that were not directly reflected in changes in gene expression. In addition to $\alpha 3 \beta 4, \alpha 3 \beta 2$ and $\alpha 4 \beta 2$ (more likely the $\beta 2$-subunit as reported by Zhou et al., 2002) contributed to the increase in $\left[\mathrm{Ca}^{2+}\right]_{\mathrm{i}}$ responses examined at P10-P11 and adult. Functional synapses between enteric neurons are present by birth to mediate gut motility (Vannucchi and Faussone-Pellegrini, 2000; Roberts et al., 2010; Foong et al., 2012). However, significant anatomical and physiological changes in the ENS occur postnatally (Roberts et al., 2007; Patel et al., 2010; Foong et al., 2012; Kabouridis et al., 2015; Rao and Gershon, 2015), and some of these changes may be facilitated by neuronal communication.
Further, there is evidence for developmental plasticity of synaptic connections during early postnatal stages (Foong et al., 2012). Thus, like the developing CNS, nAChRs may play major roles in target selection and formation of synapses in the developing ENS (Liu et al., 2007). Future studies are required to develop assays for enteric synaptogenesis to test whether neuronal activity and nAChRs, along with genetic programs (Sasselli et al., 2013), are important for enteric synapse and circuit formation.

\section{Unconventional nAChRs present early during ENS development}

In all postnatal ages examined, DMPP evoked increases in $\left[\mathrm{Ca}^{2+}\right]_{\mathrm{i}}$ that were almost completely abolished by hexamethonium. Surprisingly, application of DMPP in E12.5 proximal small intestine evoked a calcium response that had a prominent hexamethonium-insensitive component $(40 \pm 2 \%$ of the control). Furthermore, application of DMPP in the less mature E12.5 colon evoked responses that were unaffected by hexamethonium. These DMPP responses were very small compared with the responses observed in the small intestine. In addition, $70 \%$ of the nicotine-evoked increase in $\left[\mathrm{Ca}^{2+}\right]_{\mathrm{i}}$ was hexamethonium insensitive. To our knowledge, there are no known nonspecific effects of DMPP or hexamethonium, but transient expression of nicotinic receptors during embryogenesis that are not affected by hexamethonium remains a possibility. The pentameric nAChRs have an extracellular domain with agonist binding sites at the boundary between subunits and a transmembrane domain lining the ion channel, which has sites for allosteric modulators (Changeux, 2010; Papke, 2014). Classical nAChR antagonists such as 
hexamethonium and mecamylamine are weak in displacing $\left[{ }^{3} \mathrm{H}\right](-)$-nicotine from its binding site; instead they bind to the allosteric site on the receptor ionophore. In the rat cerebral cortex, more than one allosteric site that binds different nAChR antagonists has been proposed (Loiacono et al., 1993). Thus it is possible that DMPP and nicotine are activating receptors at E12.5 that do not have the allosteric binding site for hexamethonium.

\section{nAChR subtypes involved in synaptic transmission in the ENS}

At all ages, the electrically and chemically stimulated responses were sharp and immediate, which is characteristic of neuronal, and not glial, responses (Boesmans et al., 2013, Laranjeira et al., 2011). Furthermore, cells expressing markers of mature glia are not present in the mouse ENS at E12.5 (Rothman et al., 1986; Young et al., 2003).

In agreement with studies in the guinea pig and rat (Kirchgessner and Liu, 1998; Obaid et al., 2005; Garza et al., 2009), we found expression of $\alpha 3, \alpha 4, \alpha 7, \beta 2$, and $\beta 4 \mathrm{nAChR}$ subunits in the adult and embryonic mouse gut. Obaid et al. (2005) proposed that the guinea pig ENS contains heteropentameric structures of $\alpha 3 \beta 2, \alpha 3 \beta 4$, and/or $\alpha 3 \beta 2 \beta 4$ (with potential addition of $\alpha 5$ ), and homopentameric $\alpha 7 \mathrm{nAChRs}$. Nicotinic receptors can be located presynaptically or postsynaptically (Galligan, 1999; Obaid et al., 2005). While there is strong evidence for the involvement of $\alpha 3 \beta 2$ and particularly $\alpha 3 \beta 4 \mathrm{nAChRs}$ in synaptic transmission, the contributions of $\alpha 7 \mathrm{~s}$ remain elusive in the myenteric plexus (Zhou et al., 2002; Galligan and North, 2004; Obaid et al., 2005). Zhou et al. (2002) showed that $\alpha 7$ antagonists (including MLA) did not affect ACh-induced responses in isolated myenteric neurons in culture. However, voltage-sensitive dye experiments revealed a potential role for $\alpha 7 \mathrm{nAChRs}$ as modulators of transmitter release (Obaid et al., 2005). In agreement with the guinea pig studies, we report significant contributions of $\alpha 3 \beta 2$ and especially $\alpha 3 \beta 4$ in chemically and electrically evoked $\left[\mathrm{Ca}^{2+}\right]_{\mathrm{i}}$ in the murine ENS. The $\alpha 4 \beta 2$ antagonist also significantly reduced responses in the P10-P11 and adult mouse myenteric plexus, but this could be due to blockade of $\beta 2$-subunits specifically as previously reported (Zhou et al., 2002). Furthermore, $\alpha 7$ blockade did not affect the responses evoked by DMPP or singlepulse electrical stimulation. This is consistent with the observation that $\alpha 7$ receptors are located on non-neural cells, notably macrophages, in the adult intestine (Tsuchida et al., 2011; Matteoli et al., 2014). However, we did find that $\alpha 7$ receptor blockade reduced responses to trains of stimuli suggesting effects on release of transmitters other than ACh; also, our study could not detect presynaptic effects similar to those identified by Obaid et al. (2005). Therefore, we cannot completely rule out the possibility of $\alpha 7$ s contributing to synaptic transmission or transmitter release in the mouse myenteric plexus.

We showed that the effects of combined addition of $\alpha 3 \beta 2$, $\alpha 3 \beta 4$, and $\alpha 4 \beta 2$ antagonists still yielded a substantial residual response to DMPP-evoked $\left[\mathrm{Ca}^{2+}\right]_{\mathrm{i}}$ compared with the nonspecific antagonist, hexamethonium. This shows possible involvement of other nAChR subunits not examined pharmacologically. We did not examine the combined drug effect on responses to electrical stimulation due to the known involvement of other neurotransmitters and our finding that only the $\alpha 3 \beta 4$ antagonist had significant effects at $\mathrm{P} 0$ and younger.

\section{Conclusions}

Our study is the first to examine nAChRs in the mature and developing mouse ENS. The nAChRs involved in chemically and electri- cally evoked calcium responses were similar to adults by P10. nAChRs mediating responses examined from E12.5 to birth involved less diverse nAChRs subunits compared with the more mature ENS. Moreover unconventional hexamethonium-insensitive nicotinic receptors are present at E12.5. Although we did not find any role for nAChRs in ENCC migration, differentiation, or neuritogenesis, nAChRs may play roles in target selection and/or synaptogenesis or circuit functionality during embryonic and postnatal development.

\section{References}

Albuquerque EX, Pereira EF, Alkondon M, Rogers SW (2009) Mammalian nicotinic acetylcholine receptors: from structure to function. Physiol Rev 89:73-120. CrossRef Medline

Alkondon M, Pereira EF, Wonnacott S, Albuquerque EX (1992) Blockade of nicotinic currents in hippocampal neurons defines methyllycaconitine as a potent and specific receptor antagonist. Mol Pharmacol 41:802-808. Medline

Anderson RB, Turner KN, Nikonenko AG, Hemperly J, Schachner M, Young HM (2006) The cell adhesion molecule 11 is required for chain migration of neural crest cells in the developing mouse gut. Gastroenterology 130:1221-1232. CrossRef Medline

Boesmans W, Martens MA, Weltens N, Hao MM, Tack J, Cirillo C, Vanden Berghe P (2013) Imaging neuron-glia interactions in the enteric nervous system. Front Cell Neurosci 7:183. CrossRef Medline

Cartier GE, Yoshikami D, Gray WR, Luo S, Olivera BM, McIntosh JM (1996) A new alpha-conotoxin which targets alpha3beta2 nicotinic acetylcholine receptors. J Biol Chem 271:7522-7528. CrossRef Medline

Changeux JP (2010) Nicotine addiction and nicotinic receptors: lessons from genetically modified mice. Nat Rev Neurosci 11:389-401. CrossRef Medline

Danielian PS, Muccino D, Rowitch DH, Michael SK, McMahon AP (1998) Modification of gene activity in mouse embryos in utero by a tamoxifeninducible form of Cre recombinase. Curr Biol 8:1323-1326. CrossRef Medline

Erickson CS, Lee SJ, Barlow-Anacker AJ, Druckenbrod NR, Epstein ML, Gosain A (2014) Appearance of cholinergic myenteric neurons during enteric nervous system development: comparison of different ChAT fluorescent mouse reporter lines. Neurogastroenterol Motil 26:874-884. CrossRef Medline

Foong JP, Nguyen TV, Furness JB, Bornstein JC, Young HM (2012) Myenteric neurons of the mouse small intestine undergo significant electrophysiological and morphological changes during postnatal development. J Physiol 590:2375-2390. CrossRef Medline

Foong JP, Tough IR, Cox HM, Bornstein JC (2014) Properties of cholinergic and non-cholinergic submucosal neurons along the mouse colon. J Physiol 592:777-793. CrossRef Medline

Furness JB (2012) The enteric nervous system and neurogastroenterology. Nat Rev Gastroenterol Hepatol 9:286-294. CrossRef Medline

Galligan JJ (1999) Nerve terminal nicotinic cholinergic receptors on excitatory motoneurons in the myenteric plexus of guinea pig intestine. J Pharmacol Exp Ther 291:92-98. Medline

Galligan JJ, North RA (2004) Pharmacology and function of nicotinic acetylcholine and $\mathrm{P} 2 \times$ receptors in the enteric nervous system. Neurogastroenterol Motil 16 [Suppl 1]:64-70. CrossRef Medline

Garza A, Huang LZ, Son JH, Winzer-Serhan UH (2009) Expression of nicotinic acetylcholine receptors and subunit messenger RNAs in the enteric nervous system of the neonatal rat. Neuroscience 158:1521-1529. CrossRef Medline

Gershon MD (1998) V. Genes, lineages, and tissue interactions in the development of the enteric nervous system. Am J Physiol 275:G869-G873. Medline

Gwynne RM, Bornstein JC (2007) Synaptic transmission at functionally identified synapses in the enteric nervous system: roles for both ionotropic and metabotropic receptors. Curr Neuropharmacol 5:1-17. CrossRef Medline

Hao MM, Moore RE, Roberts RR, Nguyen T, Furness JB, Anderson RB, Young HM (2010) The role of neural activity in the migration and differentiation of enteric neuron precursors. Neurogastroenterol Motil 22: e127-e137. CrossRef Medline

Hao MM, Boesmans W, Van den Abbeel V, Jennings EA, Bornstein JC, Young 
HM, Vanden Berghe P (2011) Early emergence of neural activity in the developing mouse enteric nervous system. J Neurosci 31:15352-15361. CrossRef Medline

Hao MM, Lomax AE, McKeown SJ, Reid CA, Young HM, Bornstein JC (2012) Early development of electrical excitability in the mouse enteric nervous system. J Neurosci 32:10949-10960. CrossRef Medline

Hao MM, Bornstein JC, Young HM (2013a) Development of myenteric cholinergic neurons in ChAT-Cre;R26R-YFP mice. J Comp Neurol 521: 3358-3370. CrossRef Medline

Hao MM, Bornstein JC, Vanden Berghe P, Lomax AE, Young HM, Foong JP (2013b) The emergence of neural activity and its role in the development of the enteric nervous system. Dev Biol 382:365-374. CrossRef Medline

Hearn CJ, Young HM, Ciampoli D, Lomax AE, Newgreen D (1999) Catenary cultures of embryonic gastrointestinal tract support organ morphogenesis, motility, neural crest cell migration, and cell differentiation. Dev Dyn 214:239-247. CrossRef Medline

Hotta R, Stamp LA, Foong JP, McConnell SN, Bergner AJ, Anderson RB, Enomoto H, Newgreen DF, Obermayr F, Furness JB, Young HM (2013) Transplanted progenitors generate functional enteric neurons in the postnatal colon. J Clin Invest 123:1182-1191. CrossRef Medline

Kabouridis PS, Lasrado R, McCallum S, Chng SH, Snippert HJ, Clevers H, Pettersson S, Pachnis V (2015) Microbiota controls the homeostasis of glial cells in the gut lamina propria. Neuron 85:289-295. CrossRef Medline

Karadsheh MS, Shah MS, Tang X, Macdonald RL, Stitzel JA (2004) Functional characterization of mouse alpha4beta2 nicotinic acetylcholine receptors stably expressed in HEK293T cells. J Neurochem 91:1138-1150. CrossRef Medline

Kirchgessner AL, Liu MT (1998) Immunohistochemical localization of nicotinic acetylcholine receptors in the guinea pig bowel and pancreas. J Comp Neurol 390:497-514. CrossRef Medline

Lake JI, Heuckeroth RO (2013) Enteric nervous system development: migration, differentiation, and disease. Am J Physiol Gastrointest Liver Physiol 305:G1-G24. CrossRef Medline

Laranjeira C, Sandgren K, Kessaris N, Richardson W, Potocnik A, Vanden Berghe P, Pachnis V (2011) Glial cells in the mouse enteric nervous system can undergo neurogenesis in response to injury. J Clin Invest 121:3412-3424. CrossRef Medline

Li Z, Caron MG, Blakely RD, Margolis KG, Gershon MD (2010) Dependence of serotonergic and other nonadrenergic enteric neurons on norepinephrine transporter expression. J Neurosci 30:16730-16740. CrossRef Medline

Li Z, Chalazonitis A, Huang YY, Mann JJ, Margolis KG, Yang QM, Kim DO, Côté F, Mallet J, Gershon MD (2011) Essential roles of enteric neuronal serotonin in gastrointestinal motility and the development/survival of enteric dopaminergic neurons. J Neurosci 31:8998-9009. CrossRef Medline

Liu Z, Zhang J, Berg DK (2007) Role of endogenous nicotinic signaling in guiding neuronal development. Biochem Pharmacol 74:1112-1119. CrossRef Medline

Loiacono R, Stephenson J, Stevenson J, Mitchelson F (1993) Multiple binding sites for nicotine receptor antagonists in inhibiting [3H](-)-nicotine binding in rat cortex. Neuropharmacology 32:847-853. CrossRef Medline

Martens MA, Boesmans W, Vanden Berghe P (2014) Calcium imaging at $\mathrm{kHz}$ frame rates resolves millisecond timing in neuronal circuits and varicosities. Biomed Opt Express 5:2648 -2661. CrossRef Medline

Matteoli G, Gomez-Pinilla PJ, Nemethova A, Di Giovangiulio M, Cailotto C, van Bree SH, Michel K, Tracey KJ, Schemann M, Boesmans W, Vanden Berghe P, Boeckxstaens GE (2014) A distinct vagal anti-inflammatory pathway modulates intestinal muscularis resident macrophages independent of the spleen. Gut 63:938-948. CrossRef Medline

Nishiyama C, Uesaka T, Manabe T, Yonekura Y, Nagasawa T, Newgreen DF, Young HM, Enomoto H (2012) Trans-mesenteric neural crest cells are the principal source of the colonic enteric nervous system. Nat Neurosci 15:1211-1218. CrossRef Medline
Nurgali K, Stebbing MJ, Furness JB (2004) Correlation of electrophysiological and morphological characteristics of enteric neurons in the mouse colon. J Comp Neurol 468:112-124. CrossRef Medline

Obaid AL, Nelson ME, Lindstrom J, Salzberg BM (2005) Optical studies of nicotinic acetylcholine receptor subtypes in the guinea-pig enteric nervous system. J Exp Biol 208:2981-3001. CrossRef Medline

Papke RL (2014) Merging old and new perspectives on nicotinic acetylcholine receptors. Biochem Pharmacol 89:1-11. CrossRef Medline

Patel BA, Dai X, Burda JE, Zhao H, Swain GM, Galligan JJ, Bian X (2010) Inhibitory neuromuscular transmission to ileal longitudinal muscle predominates in neonatal guinea pigs. Neurogastroenterol Motil 22:909918:e236-e237. CrossRef Medline

Rao M, Gershon MD (2015) Bugs, guts, and glia: how microbiota influence enteric gliogenesis and migration. Neuron 85:229-230. CrossRef Medline

Roberts RR, Murphy JF, Young HM, Bornstein JC (2007) Development of colonic motility in the neonatal mouse-studies using spatiotemporal maps. Am J Physiol Gastrointest Liver Physiol 292:G930-G938. CrossRef Medline

Roberts RR, Ellis M, Gwynne RM, Bergner AJ, Lewis MD, Beckett EA, Bornstein JC, Young HM (2010) The first intestinal motility patterns in fetal mice are not mediated by neurons or interstitial cells of Cajal. J Physiol 588:1153-1169. CrossRef Medline

Roosen L, Boesmans W, Dondeyne M, Depoortere I, Tack J, Vanden Berghe P (2012) Specific hunger- and satiety-induced tuning of guinea pig enteric nerve activity. J Physiol 590:4321-4333. CrossRef Medline

Rothman TP, Gershon MD (1982) Phenotypic expression in the developing murine enteric nervous system. J Neurosci 2:381-393. Medline

Rothman TP, Tennyson VM, Gershon MD (1986) Colonization of the bowel by the precursors of enteric glia: studies of normal and congenitally aganglionic mutant mice. J Comp Neurol 252:493-506. CrossRef Medline

Sasselli V, Pachnis V, Burns AJ (2012) The enteric nervous system. Dev Biol 366:64-73. CrossRef Medline

Sasselli V, Boesmans W, Vanden Berghe P, Tissir F, Goffinet AM, Pachnis V (2013) Planar cell polarity genes control the connectivity of enteric neurons. J Clin Invest 123:1763-1772. CrossRef Medline

Takarada T, Nakamichi N, Kitajima S, Fukumori R, Nakazato R, Le NQ, Kim YH, Fujikawa K, Kou M, Yoneda Y (2012) Promoted neuronal differentiation after activation of alpha4/beta2 nicotinic acetylcholine receptors in undifferentiated neural progenitors. PLoS One 7:e46177. CrossRef Medline

Tsuchida Y, Hatao F, Fujisawa M, Murata T, Kaminishi M, Seto Y, Hori M, Ozaki H (2011) Neuronal stimulation with 5-hydroxytryptamine 4 receptor induces anti-inflammatory actions via alpha7nACh receptors on muscularis macrophages associated with postoperative ileus. Gut 60:638 647. CrossRef Medline

Vannucchi MG, Faussone-Pellegrini MS (2000) Synapse formation during neuron differentiation: an in situ study of the myenteric plexus during murine embryonic life. J Comp Neurol 425:369-381. CrossRef Medline

Young HM, Bergner AJ, Müller T (2003) Acquisition of neuronal and glial markers by neural crest-derived cells in the mouse intestine. J Comp Neurol 456:1-11. CrossRef Medline

Zariwala HA, Borghuis BG, Hoogland TM, Madisen L, Tian L, De Zeeuw CI, Zeng H, Looger LL, Svoboda K, Chen TW (2012) A Cre-dependent GCaMP3 reporter mouse for neuronal imaging in vivo. J Neurosci 32: 3131-3141. CrossRef Medline

Zaveri N, Jiang F, Olsen C, Polgar W, Toll L (2010) Novel alpha3beta4 nicotinic acetylcholine receptor-selective ligands. Discovery, structure-activity studies, and pharmacological evaluation. J Med Chem 53:8187-8191. CrossRef Medline

Zhong LR, Estes S, Artinian L, Rehder V (2013) Acetylcholine elongates neuronal growth cone filopodia via activation of nicotinic acetylcholine receptors. Dev Neurobiol 73:487-501. CrossRef Medline

Zhou X, Ren J, Brown E, Schneider D, Caraballo-Lopez Y, Galligan JJ (2002) Pharmacological properties of nicotinic acetylcholine receptors expressed by guinea pig small intestinal myenteric neurons. J Pharmacol Exp Ther 302:889-897. CrossRef Medline 